\title{
THE RESEARCH FOR RELIABILITIES OF PE NATURAL GAS TRANSFERRING LINES JOINING WITH BUTT FUSION WELDING IN DIFFERENT TEMPERATURES
}

\author{
SICAK ALIN KAYNAK YÖNTEMİ İLE FARKLI SICAKLIKLARINDA \\ BİRLEŞTİIILEN PE DOĞALGAZ TRANSFER HATLARININ GÜVENİRLİKLERİNINN \\ ARAŞTIRILMASI
}

\author{
Adnan AKKURT1 ${ }^{*}$, Erkan SARAC ${ }^{2}$ \\ 1Endüstriyel Tasarım Mühendisliği Bölümü, Teknoloji Fakültesi, Gazi Üniversitesi, Ankara, Türkiye. \\ aakkurt@gazi.edu.tr \\ ${ }^{2}$ NTG Plastik Sanayi ve Ticaret AȘ, İstanbul, Türkiye. \\ erkansarac2001@yahoo.com
}

Received/Geliş Tarihi: 19.03.2014, Accepted/Kabul Tarihi: 27.06.2014

* Corresponding author/Yazışılan Yazar

doi: $10.5505 /$ pajes. 2014.81300

Abstract

This study focused on the reliabilities of PE plastic natural gas transferring lines. This lines can be damaged like stretching, twisting, cramping, springing, etc. occurring due to the surface movements happening on the ground layers. Natural gas transferring lines have major effects on the reliabilities of the lines. The study reveals the effect of ambient temperatures in which these lines are established or repaired. Experimental measurements and tests applied on the sample sets acquired from the butt joined lines at different ambient temperature between $+60{ }^{\circ} \mathrm{C}$ and $-25{ }^{\circ} \mathrm{C}$ temperature intervals with fusion welding method. Experimental studies have shown that pipe quality (Plastic structure and production of plastic material) is an important parameter on the heating and pressure times. The result of the study shows that ambient temperature of the joining process is an effective parameter on the heating and pressure time of PE plastic.

Keywords: Plastic welding, Butt fusion welding, Line safety, Different ambient temperature

\section{Introduction}

Plastic and composite materials takes the place of wood, metal, ceramic and other materials in different qualities. At the welding of plastic materials, the material characteristics, working conditions, changes in temperature, hardening aptitude after welding, chemical resistance of material, process safety other than heat resistance, welding reliability effects weldability of plastic based materials. Thermoplastic materials have these properties. Joining methods with mechanic equipments are used for joining of the plastic materials other than thermoplastics [1]-[3]. Welded joints must be free from any kind of stresses much as possible. Stresses which may arise form differences in temperature between laying and operating conditions must be kept as low as possible by taking appropriate measures. In Table 1 welding methods for PE materials are given [4]. As a result, bead heights may change according to the MFR (melt flow rate) value of the raw material of pipe. The pipe's mixtures except PE100 affect the bead geometry (spatial and modal) even if the pipe is the same in both sides [14].

Joining PE (polyethylene) Plastic Pipes: The welding methods of plastics have advantages and disadvantages. Butt
Öz

Ülkemiz gibi depremlerin çok sık yașandığı ve yılın her anında farklı sıcaklıkların yaşandığı ülkelerde PE plastik doğalgaz transfer hatlarının güvenirliklerinin araștırılmasına yönelik yapılan bu çalıșma göstermiştir ki, doğalgaz hatlarını taşıyan toprak katmanlarında meydana gelen yeryüzü hareketlerinin sebep olduğu esneme, bükülme, burulma, çarpılma vb. olumsuzlukların olușturduğu tahribatlar hat güvenirlikleri üzerinde büyük etkilere sahiptir. Bütün bunların dışında bu hatların olușturulduğu veya yukarda belirtilen olumsuz çevre koşullarının sebep olduğu zararların onarımların yapıldığı sıcaklıkların da büyük öneme sahip olduğu bu çalıșa ile ortaya konmaktadır. Sıcak alın kaynağı ile $+60{ }^{\circ} C^{\prime}$ den $-20{ }^{\circ} \mathrm{C}$ sicaklık aralıklarında farklı kademelerde yapılan birleștirmelerden elde edilen numunelere uygulanan ölçüm ve testler (TS ISO 13954) göstermiștir ki boru kalitesi ısıtma ve basınç süreleri üzerinde önemli bir parametredir. Birlestirme ișleminin yapıldığı ortam sıcaklığı kaynak kalitesi üzerinde çok etkin bir parametredir.

Anahtar kelimeler: Plastik kaynağı, Sıcak elaman kaynağı, Hat güvenliği, Farklı ortam sıcaklıkları

fusion welding and electrofusion welding are commonly used for welding of plastic materials. Performance of the joints that obtained with butt fusion welding is depended on choosing the right parameters below;

Temperature: External surfaces to weld are softened by heat. Direct flame is not preferable due to the adverse thermal conductivity of plastics because the plastic burns up. In case heated plastics are cooled suddenly with a compressed air or water, stress occurs on the welding areas.

Pressure: Plastic becomes viscose when melted, the fibers in each part should be supported with pressure.

Time: Because of the very low thermal conductivities of plastic materials, the time of heat input and cooling time should be adjusted carefully. Excess heat causes thermal damages. Expansion and contraction of plastics are much more than metals while heating and cooling, possible problems should be taken into account [5]-[8]. The welding parameters recommended as ISO 11414 standards for butt fusion welding processes are given in Table 2 [9]. 
Table 1: Welding methods for PE materials [4].

\begin{tabular}{|c|c|c|c|c|c|c|c|c|}
\hline \multirow{2}{*}{$\begin{array}{l}\text { Kind of joint } \\
\text { Heating element butt welding (HS) }\end{array}$} & \multicolumn{2}{|c|}{$\begin{array}{c}\emptyset 20-63 \\
<\text { PN6 >=PN6 }\end{array}$} & \multicolumn{2}{|c|}{$\begin{array}{c}\emptyset 63-110 \\
<\text { PN6 >=PN6 }\end{array}$} & \multicolumn{2}{|c|}{$\emptyset 110-225$} & \multicolumn{2}{|c|}{$\begin{array}{l}\emptyset 225-1400 \\
<\text { PN6 >=PN6 }\end{array}$} \\
\hline & A B C & A-E & A B C & $\mathrm{A}-\mathrm{E}$ & A B C & $\left.A-E^{3}\right)$ & A B C & A B C D \\
\hline Non-contact butt welding (Infrared - IR) & A D & A D E & A & A D E & A & A D E & - & - \\
\hline Beadles butt welding (IS) & A B C & A B C & A B C & A B C & A B C1) & $\mathrm{A} \mathrm{B} \mathrm{C}^{11}$ & - & - \\
\hline Heating element socket welding & - & A B C D & A B C & $\begin{array}{l}\text { A B C } \\
\text { D }\end{array}$ & - & - & - & - \\
\hline $\begin{array}{l}\text { Electric socket welding (hot wedge } \\
\text { welding) }\end{array}$ & - & A B C D & A B C & A B C & $\mathrm{B}$ & A B & $\mathrm{B}^{2)}$ & $\mathrm{B}^{2)}$ \\
\hline $\begin{array}{l}\text { Hot gas welding } \\
\text { Extrusion welding }\end{array}$ & A - E & A- E & A - E & A - E & $\begin{array}{l}A-E \\
A-D\end{array}$ & A- D & A- D & $A-D$ \\
\hline $\begin{array}{l}\text { Flange Joint } \\
\text { Union }\end{array}$ & $\begin{array}{l}A-E \\
A-E\end{array}$ & $\begin{array}{l}A-E \\
A-E\end{array}$ & $A-E$ & $A-E$ & $\left.A-E^{3}\right)$ & $A-D$ & $A-D^{4)}$ & $A-D^{4)}$ \\
\hline $\begin{array}{l}A=P P-H 100, P P-R 80 \\
B=P E \\
C=\text { Special types (PE80-el, pp-h-s, PP-R-s- }\end{array}$ & \multicolumn{2}{|c|}{$\begin{array}{l}\mathrm{D}=\mathrm{PVDF} \\
\mathrm{E}=\mathrm{ECTFE}\end{array}$} & & \multicolumn{3}{|c|}{$\begin{array}{l}\text { 1) up to } \emptyset 160 \\
\text { 2) < } \text { PN6 up to Ø600 }\end{array}$} & \multicolumn{2}{|c|}{$\begin{array}{l}\text { 3) up to } \emptyset 160 \\
\text { 4) up to } \emptyset 315\end{array}$} \\
\hline
\end{tabular}

Table 2: Recommended parameters for butt fusion welding processes [9].

\begin{tabular}{ccccc}
\hline & \multicolumn{2}{c}{ Ambient Temperature } & Heating Tool Temperature $(\mathrm{T})$ & Butt Welding Pressure $(\mathrm{P})$ \\
\cline { 2 - 4 } Conditions & Symbol & Value $\left({ }^{\circ} \mathrm{C}\right)$ & $\left({ }^{\circ} \mathrm{C}\right)$ & $\left(\mathrm{N} / \mathrm{mm}^{2}\right)$ \\
Min. & Tmin. & $-5^{*}$ & $205 \pm 5^{*}$ & $0.015 \pm 0.02^{*}$ \\
Max. & Tmax. & $40+2^{*}$ & $230 \pm 5^{*}$ & $0.021 \pm 0.02^{*}$
\end{tabular}

*Values recommended in standards.

Welding Process of PE Material: The joining environment should protect from adverse environmental conditions such as excessive sunlight, damp, dust, the temperature low than $-5^{\circ} \mathrm{C}$ or high than $20^{\circ} \mathrm{C}$, etc. This is because such adverse factors may cause irregular heating on the welding area. PE materials to be joined with this method should be at the same properties and wall thickness. Proper joining temperatures should be chosen according to the wall thicknesses of the materials to be joined (Figure 1), [5],[8],[10].

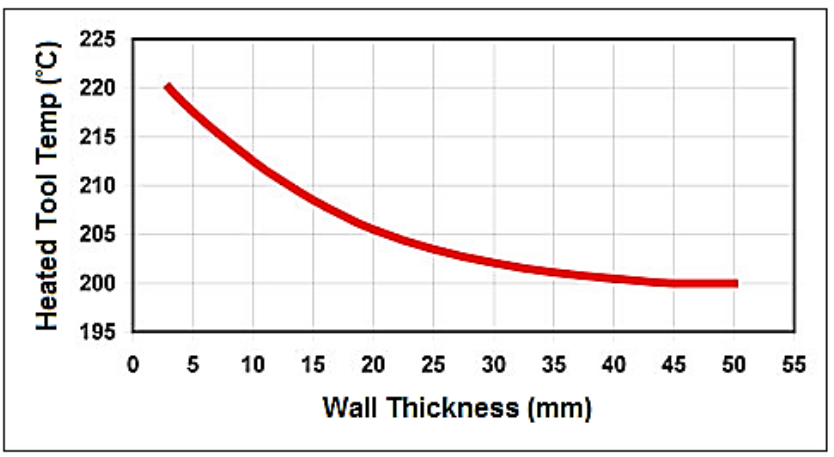

Figure 1: Joining temperature changes according to the wall thickness of pipe.

The surfaces to be joined should be clean and perpendicular to each other. Pressure should be exerted until the desired weld bead height at the standards (ASTM F2620-06) is finally gained on the joining area, according to the diameter of the material and the wall thickness. Components should not move before the joining area cool down completely [11],[12].

Heating Element Butt Welding: Heating element of butt welding warms the parts up to the requested welding temperature. Generally the higher temperatures for smaller wall thicknesses and the lower temperatures for larger wall thicknesses is used [4],[11],[13].
In this study, butt fusion welding method is used for joining PE pipes which are widely used for transferring natural gas. Joining processes were performed at different ambient temperatures (from $-25{ }^{\circ} \mathrm{C}$ to $+60{ }^{\circ} \mathrm{C}$ ). Different tests are applied to the samples made up from the welded joints and the results are evaluated.

\section{Material and Methods}

\subsection{Material}

Polyethylene (PE 100) plastic pipe used for natural gas transferring is used in this study. General characteristics of the PE 100 material are given on Table 3. Because of its elasticity, polyethylene is not affected from earthquakes and avalanches. It keeps its elasticity features even at the temperatures of $-40{ }^{\circ} \mathrm{C}$. It shows high resistance against chemicals. It also has high resistance against erosion and corrosion. It is 8 times lighter than metal because of its low density. It works properly minimum 50 years with a nominal working pressure. It is $100 \%$ impermeable and it does not make assembling leakage. It does not change the features of water, gas, petrol or chemicals it carries. It shows high impact resistance at low temperatures. It is durable to environmental conditions. It is resistant to UV rays. The production of polyethylene (PE) plastic pipes is standardized by EN ISO 1872-1. Although $100 \%$ original raw material of PE100 pipe or particular amount of recycling fragments should be used, polymer structure of the pipe is corrupted by adding compounds of junk and plastic, calcite and talk. This affects the quality of weld especially during the welding processes. Therefore, the heating element temperature is increased from $220{ }^{\circ} \mathrm{C}$ to $230{ }^{\circ} \mathrm{C}$ and the waiting time at the non-pressure heating element increased $15 \%$.

\subsection{Method}

PE100 plastic pipes at the diameter of $125 \mathrm{~mm}$ are applied joining processes at different temperatures with ALD 160 welding machine (characteristics of welding machine and 
joining parameters are given in Table 4). All parameters are chosen fixed except the ambient temperature. Test samples are prepared in standard dimensions as seen in Figure 2. Tests were performed according to the standards of ISO 13953. Test, number varied from 4 to 8 at the room temperature of $23{ }^{\circ} \mathrm{C}$ and at a permanent speed of $5 \mathrm{~mm} / \mathrm{min}$ tensile tests.

Numerical results are determined by the arithmetic average. In this study, (PE) plastic pipes welded in butt form with fusion welding.

Application: Before welding procedure the PE pipes were waited for 5 hours in deep freezer and then butt welded. The selected parameters of the welding processes are given in Figure 3.
The tests applied to the samples that are joined according to ISO 4427, ISO 4437, ISO 8085-2 and ISO/TR 11647:1996 standards and their results are summarized in this study.

Butt fusion welding temperature and the process time is given in Figure 4. In this study, as it can be seen in the Figure 4, there is a significant difference in temperature between the external welding bead surface and the center during the welding processes that are made by a heating element at a temperature of $230{ }^{\circ} \mathrm{C}$ in every ambient temperatures. This result show the similarity with literature study [14]-[20].

The study carried out to investigate the effect of ambient temperature differences between $-25{ }^{\circ} \mathrm{C}$ and $60{ }^{\circ} \mathrm{C}$ on the quality of welding. Samples joined by butt fusion welding method extents after the tensile test.

Table 3: General Characteristics of PE100 natural gas pipes.

\begin{tabular}{lll}
\hline Technical Properties & Unit & Value \\
\hline Density $\left(23^{\circ} \mathrm{C}\right)$ & $\mathrm{g} / \mathrm{cm}^{3}$ & $0.950-0.960$ \\
Melting Flow Rate (MFR) $190^{\circ} \mathrm{C}-2.16 \mathrm{Kg}$ & $\mathrm{g} / 10 \mathrm{~min}$ & $0.04-0.07$ \\
Melting Flow Rate (MFR) $190^{\circ} \mathrm{C}-5.0 \mathrm{Kg}$ & $\mathrm{g} / 10 \mathrm{~min}$ & $0.2-0.5$ \\
Tensile Stress (yield) & $\mathrm{Kg} / \mathrm{cm}^{2}$ & 255 \\
Elongation (yield) & $\%$ & 9 \\
Breaking Elongation & $\%$ & $>600$ \\
Yield Stress Endurance & $\mathrm{MPa}$ & $22-27$ \\
Elasticity Module & $\mathrm{Kg} / \mathrm{cm}^{2}$ & 11216 \\
Carbon Black Amount $\left(190^{\circ} \mathrm{C}-5.0 \mathrm{Kg}\right)$ & $\%$ & $>2.5$ \\
Hardness & $\mathrm{Shore}$ & 60 \\
Thermal Endurance & $\mathrm{min}$ & $>20$ \\
Vicat Softening Temperature & $\circ \mathrm{C}$ & 126 \\
Brittleness Temperature & ${ }^{\circ} \mathrm{C}$ & $<-70$ \\
Thermal Conductivity $\left(20^{\circ} \mathrm{C}\right)$ & $\mathrm{W} / \mathrm{mK}$ & 0.4 \\
Thermal Conductivity $\left(150^{\circ} \mathrm{C}\right)$ & $\mathrm{W} / \mathrm{mK}$ & 0.2 \\
ESRC (at $\left.50{ }^{\circ} \mathrm{C}\right), \mathrm{F} 50$ & $\mathrm{hour}$ & $>10000$ \\
\hline
\end{tabular}

Table 4: Joining parameters and welding tool characteristics.

Welding (joining) Parameters

Features of ALD 160 Welding Machine

\begin{tabular}{lll}
\hline Pre-heating temperature & $120^{\circ} \mathrm{C}$ & Suitable for ISO 12176-1 norms \\
Temperature of heating element & $280^{\circ} \mathrm{C}$ & External diameters to be welded: $\emptyset 40 \mathrm{~mm}-\emptyset 160 \mathrm{~mm}$ \\
Pressure of pre-heating & $60 \mathrm{psi}$ & Raw materials to be welded : PE and PP \\
Joining pressure & $30 \mathrm{psi}$ & Max. wall thickness to be welded (Pressure Group) : N16 \\
Changing time & $10 \mathrm{~s}$ & Electric power of heater: $230 \mathrm{~V}$ - $1500 \mathrm{~W}$ \\
Joining and cooling time & $36 \mathrm{~s}$ & Electric power of planer: $230 \mathrm{~V}-810 \mathrm{~W}$ \\
Working pressure & $130 \mathrm{bar}$ & Electric system: Menopause \\
Melt flow rate & $30 \mathrm{ml} / \mathrm{min}$ & Total electric consumption: $2.3 \mathrm{~kW}$ \\
T1-Alignment time & $30 \mathrm{~s}$ & Required generator power: $4 \mathrm{kVA}$ \\
T2-Heating time & $140 \mathrm{~s}$ & \\
T3-Cooling time & $17 \mathrm{~min}$ & \\
\hline
\end{tabular}



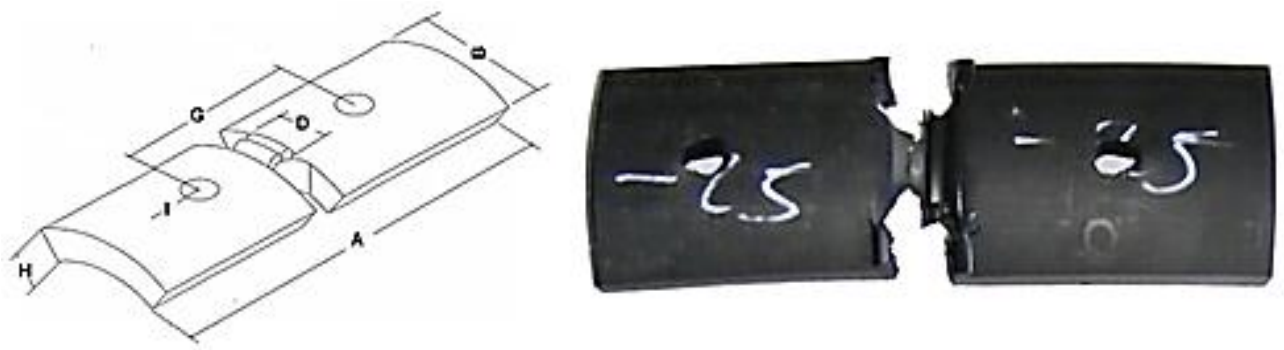

Figure 2: Tensile test sample and Fracture sample after test (ISO 13953).

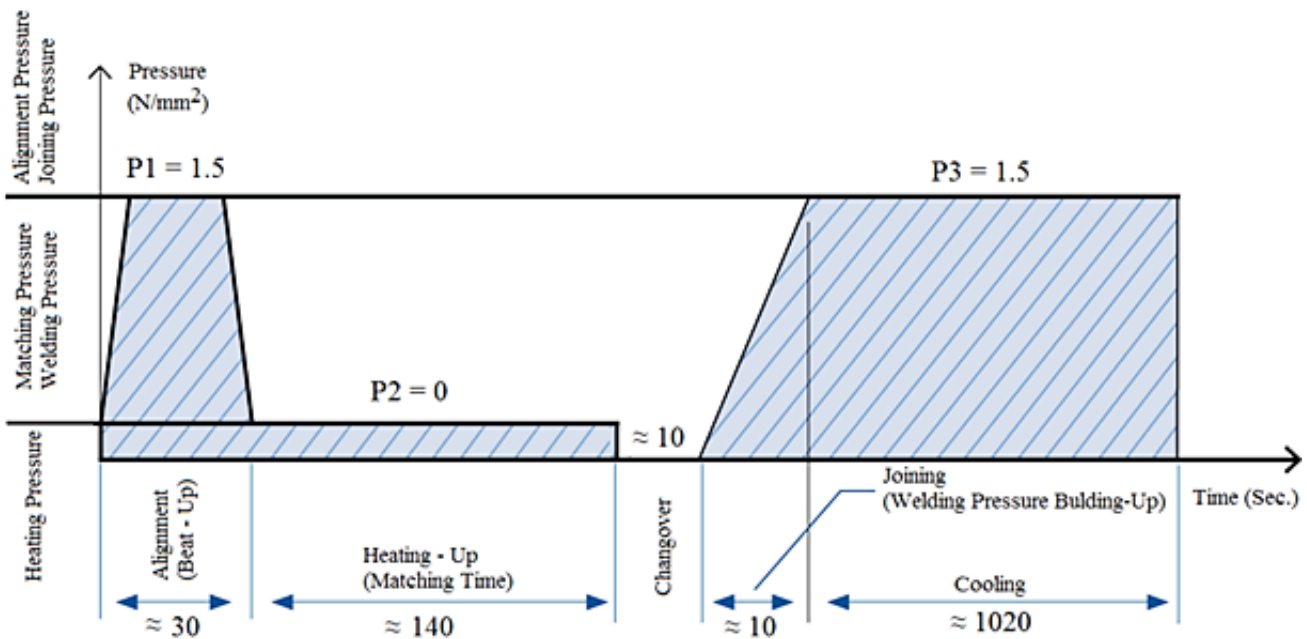

Figure 3: Process stages of butt welding [9],[10].

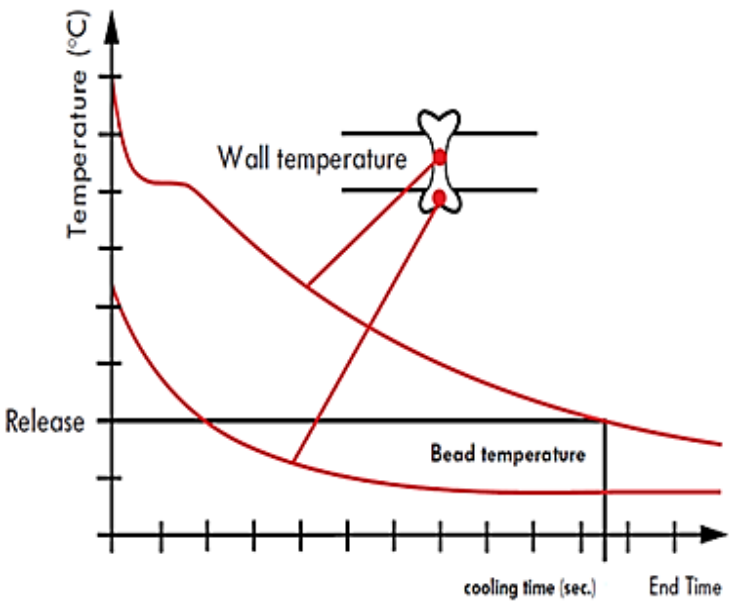

Figure 4: Temperature exchange during the butt fusion welding process of PE pipes [11].

\section{Experimental Results and Discussion}

The pipe's mixtures except PE100 affect the bead geometry (spatial and modal) even if the pipe is the same in both sides. Joined at each temperature, severing test is applied to 8 samples and achieved results are given in Table 5.

Joined at each temperature, 4 or 8 samples are prepared depending on the test to be applied and the pulling and severing tests are applied to them. The results sometimes have differences. If we have to do a generalization, the welding quality that is achieved by the standardized boundary conditions are applied is very important.

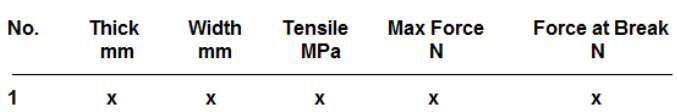

Force (N)

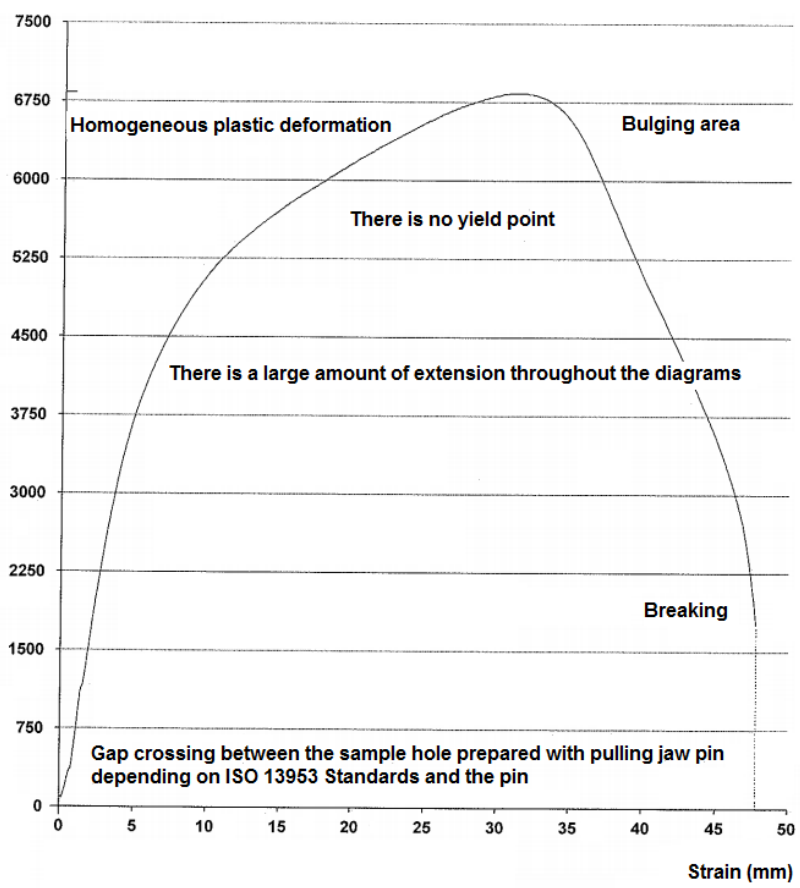

Figure 5: The graphic of image of all the joining samples. 
Table 5: Evaluation of pulling tests according to the welding success that is applied to the samples achieved depending on the joining ambient temperature.

\begin{tabular}{ccc}
\hline $\begin{array}{c}\text { Joining Ambient } \\
\text { Temperature }\left({ }^{\circ} \mathrm{C}\right)\end{array}$ & $\begin{array}{c}\text { Total Joining Time }(\mathrm{T}) \\
\text { (Standard)+(Saved or Lessened Additional Period } \\
\text { Depending on the Practitioner Experience) }\end{array}$ & $\begin{array}{c}\text { Test Result } \\
\text { (Extension) }\end{array}$ \\
\hline $60^{\circ} \mathrm{C}$ & $2+120+8+8+16=154-20 \cong 134 \mathrm{~s}$ & Extension Positive \\
$45^{\circ} \mathrm{C}$ & $2+120+8+8+16=154-20 \cong 134 \mathrm{~s}$ & Extension Positive \\
$25^{\circ} \mathrm{C}$ & $2+120+8+8+16=154-10 \cong 144 \mathrm{~s}$ & Extension Positive \\
$20^{\circ} \mathrm{C}$ & $2+120+8+8+16=154-10 \cong 144 \mathrm{~s}$ & Extension Positive \\
$15^{\circ} \mathrm{C}$ & $2+120+8+8+16=154 \mathrm{~s}$ & Extension Positive \\
$10^{\circ} \mathrm{C}$ & $2+120+8+8+16=154 \mathrm{~s}$ & Extension Positive \\
$5{ }^{\circ} \mathrm{C}$ & $2+120+8+8+16=154 \mathrm{~s}$ & Extension Positive \\
$0^{\circ} \mathrm{C}$ & $2+120+8+8+16=154 \mathrm{~s}$ & Extension Positive \\
$-5^{\circ} \mathrm{C}$ & $2+120+8+8+16=154+5 \cong 159 \mathrm{~s}$ & Extension Positive \\
$-10^{\circ} \mathrm{C}$ & $2+120+8+8+16=154+10 \cong 164 \mathrm{~s}$ & Extension Positive \\
$-15^{\circ} \mathrm{C}$ & $2+120+8+8+16=154+15 \cong 169 \mathrm{~s}$ & Extension Positive \\
$-20^{\circ} \mathrm{C}$ & $2+120+8+8+16=154+15 \cong 169 \mathrm{~s}$ & Extension Positive \\
$-25^{\circ} \mathrm{C}$ & $2+120+8+8+16=154+20 \cong 174 \mathrm{~s}$ & Extension Positive \\
\hline
\end{tabular}

Experiments are done by saving and lessening the welding periods to achieve success at temperatures of $-25^{\circ} \mathrm{C}$ and $60^{\circ} \mathrm{C}$ in other words a high quality joining. In general, welding periods are given independent to standards by the practitioners. This usually causes complications at the weld quality. However, if the welding period is not saved or lessened depending on the welding ambient temperature, joining process should not be done over the temperature of $+25{ }^{\circ} \mathrm{C}$ or under the temperature of $5{ }^{\circ} \mathrm{C}$ that are indicated by standards and literature. Therefore, welding of PE natural gas pipes or repairs of them should not be done under heavy winter conditions. High quality welding processes can be done by saving or lessening the welding period at the temperatures that are over or under the standards. Ultimate tensile strength, yield strength is given in Figure 5.

These graphics were obtained according to ISO 13954 standard. Ultimate tensile strength were calculated by dividing of the highest tensile strength to the material thickness' cross section according to the ISO 13953 standard. It is not possible to identify the yield point of sample. Strain amounts of tested samples were very close to each other. A plastic deformation which is almost homogenous is observed in all samples. Tensile strengths of tested samples showed a variety between 21-27 MPa (Figure 6).

When the graphics are examined, it is seen that the welded materials are exposed to a homogenously plastic deformation just after exceeding the yield point. Another case observed in the graphics is that the samples have a large bulge area. After bulging, the material detaches.

A high strain (stretching) is seen on the samples. Because of a high percentage of bulging, yield strength is quite less than ultimate tensile strength in all samples. The ultimate tensile strength and yield strength which are measured during the experiments are given in Figure 7.

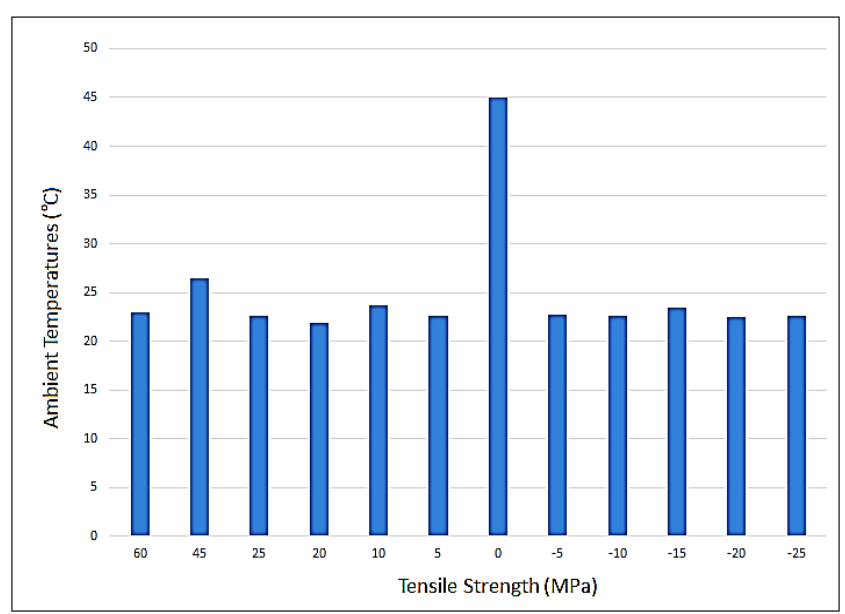

Figure 6: Pulling resistances of the samples that joined under different ambient temperatures.

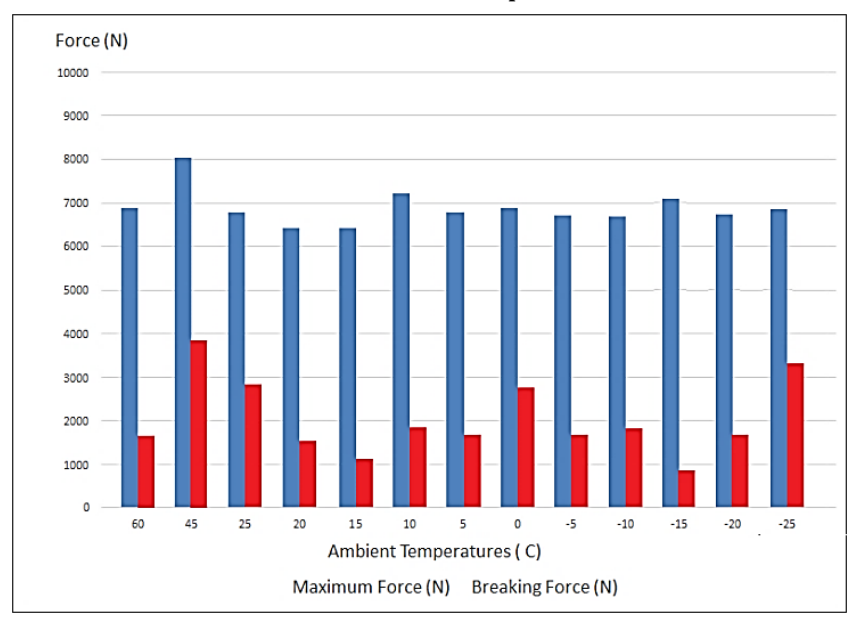

Figure 7: Comparison of detachment strength and maximum strength of the samples joined under different ambient temperatures. 
It is said that the yield strength is only saved as a standard and it may not be important when it is initially perceived. However, in practice, we can say that the yield strength is an indication of good weld. In one of the experiments which is applied to the joining gained under different ambient temperatures, when the extension amount gained with $-25^{\circ} \mathrm{C}$ is evaluated, a well-welding is obtained, whereas under the same circumstances with $-5{ }^{\circ} \mathrm{C}$, same amount of extension is obtained. When the arithmetic average of the measurements (obtained with $-25^{\circ} \mathrm{C}$ and $-5^{\circ} \mathrm{C}$ ) gained through the graphics is taken, strength difference is almost duplicated. This is quite a contradictory case for the recommended temperatures both in standards and in literature. As a result, this situation supports the thesis (that the practitioners stated) that with a little increase or decrease by experience beside the recommended temperatures can lead to very qualified results. In the evaluations of all achieved samples, the most important result that reveals the standardized welding quality is the extension (stretching) amount occurred in the test.

Another case is that it is said in butt fusion welding standard (ISO 13953) that the applied ultimate tensile strength is recorded. Another comment that can be made as a result of experience gained after one hundred and twenty experiments carried out during this study is that although it reveals that welding quality is quite high when the yield strength is also high, as a matter of fact, the important thing is to obtain a higher extension amount rather than the strength (the standards which identify the tests to be applied to other plastic welding and plastic materials).

The standards keep the highest strength gained during the tests. In this case, the fraction strengths gained under different ambient temperatures may not be taken into consideration. This is because the fraction detection of the testing machine may be different like being more extended and detecting strength till the final point, whereas in another test it may show high fraction strength by detecting the end of extension and that the strength detection is too soon. Briefly, this value is not vital. As it is stated in the standards, if there is an extension occurred on the detachment part during the tests (there is no certain expression about extension amount), in other words if the extension is realized, the joining is regarded as successful. One of the biggest disadvantages of butt fusion welding is that the bead which occurs outside the pipe also occurs inside it. This has an effect on flow rate in transferring lines and internal pipe pressure. Furthermore, some acts like starting and stopping the pumps, sudden valve shutting, and etc. cause occurrence of pulse impact on internal pipe surface. These impacts constitutes the pressures under and above the normal line pressure and although these cases are quite regular in transferring lines, as a result of these pressures, exhaustion occurs on pipe and welding areas and this leads to breaking, detachment, cracking, etc... Thus, internal pressure tests have a significant importance. Resistances in case of pressure wave occurrences in natural gas pipelines are applied to the sample sets which are shown in Figure 8a.

One of the most important factors that affect strength and useful life of the pipes that are used in natural gas transferring lines is internal and external pressures. Pressure tests are applied to the pipes in the sample sets which are joined under different ambient temperatures with butt fusion welding according to EN 1167-1 (4 samples joined under every ambient temperature).

Experiment sets each including two pend pipes with $90^{\circ}$ angle are prepared for identified ambient temperatures (Figure 8a). After the joining process of the prepared experiment sets with Ritmo Brand Butt Fusion Welding Machine, procedures that determined in the standards are applied to these sets and the results of this application is given in Table 6.

The tests are made with the same parameters that are achieved from hydrostatic internal pressure resistance. Tests applied to the experimental sample set at each temperature and their approximate resistance periods are found by finding the arithmetic averages of these resistance periods. When a general comment is made according to these diagrams, it is found out that the temperatures at $10{ }^{\circ} \mathrm{C}$ or higher are the ones that give the most perfect results and the lower temperatures give comparatively poor results.

Table 6: Results of test and measurements applied to the experiment samples.

Report of Pressure Test for PE100

\begin{tabular}{ll}
\hline Hydrostatic Resistance $\left(80^{\circ} \mathrm{C}, 165 \mathrm{~h}\right)$ & Non Damaged \\
Hydrostatic Resistance $\left(80^{\circ} \mathrm{C}, 1000 \mathrm{~h}\right)$ & Non Damaged \\
Hydrostatic Resistance $\left(20^{\circ} \mathrm{C}, 100 \mathrm{~h}\right)$ & Non Damaged \\
Hydrostatic Resistance $80^{\circ} \mathrm{C}, 165 \mathrm{~h}$ Hydrostatic & Non Damaged \\
Quality Control Report of Raw Material Density (F39) & $959 \mathrm{~kg} / \mathrm{m}^{3}$ \\
Hydrostatic Resistance $80^{\circ} \mathrm{C}, 1000 \mathrm{~h}$ Hydrostatic Pressure Test Report (F50) & Non Damaged \\
Hydrostatic Resistance $20^{\circ} \mathrm{C}, 100 \mathrm{~h}$ Hydrostatic Pressure Test Report (F50) & Non Damaged \\
Quality Control Report of Raw Material MFR (F39) & $0.40\left(190{ }^{\circ} \mathrm{C} / 5 \mathrm{~kg}\right)$ for PE100 \\
Joining Resistance Report (F 96) & $\% 100$ Boiling occurred. \\
Oxidation Induction Period & 33 min. \\
Process Control Form of Electrical Features (F-12) & $1.5 \Omega$
\end{tabular}

NON DAMAGED means there is no draining and deformation on the sample at the result of experiment. 
According to the reports that are to be example for the test reports in Figure 9, it is seen that the achieved diagrams in hydrostatic internal pressure tests especially support the pictures in Figure 8 b, c, d and e that is, the waving's occur in a very small area to the completion before the blow-up in diagrams. When the other pictures are analyzed, it is obvious that the blow-ups excluding the welding area happen as a result of the waving occurred in a longer time period.

Moreover, standard test is applied by choosing the standardized parameters, 5.0 MPa circular tension is applied to each experiment set that are prepared every at every ambient temperature and each sample is observed one by one after the test period is completed. There is no blow-up or permanent deformation determined on any 52 samples of all. 7.5 $\mathrm{MPa}$ circular tension and 15 bar hydrostatic internal pressure are applied to the other 52 experiment samples (4 samples for each ambient temperature). All samples are exposed to the bath water temperature of $80{ }^{\circ} \mathrm{C}$ until they blow-up and their blow-up periods are determined (Figure 9a,b).
More qualified joints can be achieved by changes to be done at the standardized parameters. In other words, it is revealed that these standards fail when developing technology is considered and they should be updated through the studies to be done by means of technology.

All samples blow-up on the stated pressures and test conditions. While a major part of these blow-ups occur on the pipes except for the welding area, detaches are seen at the welding areas especially at temperatures of $-15^{\circ} \mathrm{C},-20^{\circ} \mathrm{C}$ and $-25{ }^{\circ} \mathrm{C}$ (Figure $8 \mathrm{~b}, \mathrm{c}, \mathrm{d}$ and e). As a result, on the joining processes at these ambient temperatures, internal pressure increases certainly cause problems for the safety of transferring line. Since circular tension causes no damage at all the temperatures over these stated ones, influencing of pressure waves at these temperatures completely depends on the pipe quality. Pressure increases at the joining areas will not cause any problem unless it is too high. The ambient temperature of the adjoining process is also a very effective parameter on welding quality and affects the performance of welding directly.

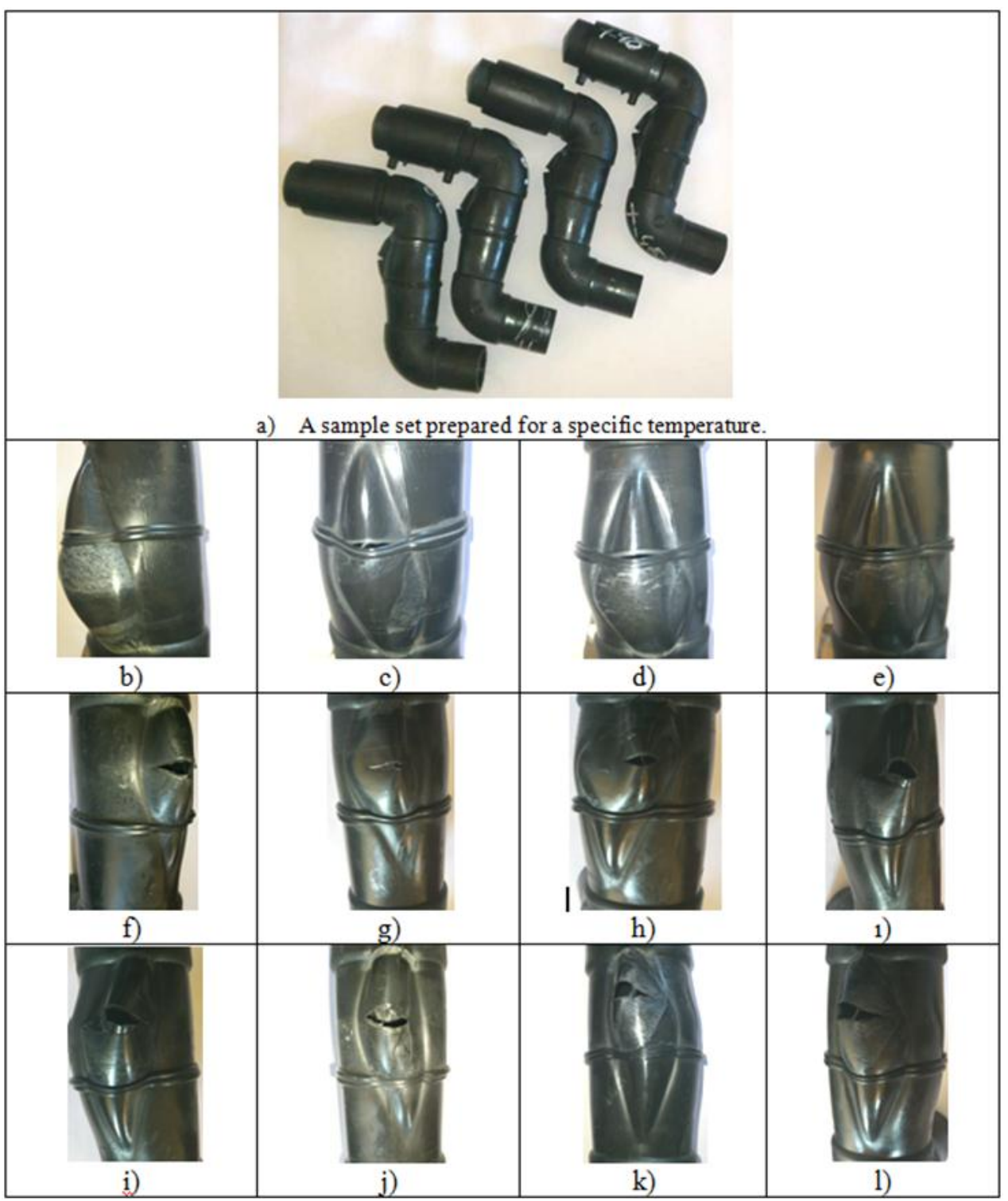

Figure 8: Images of samples joined under different ambient temperatures after the pressure test. 


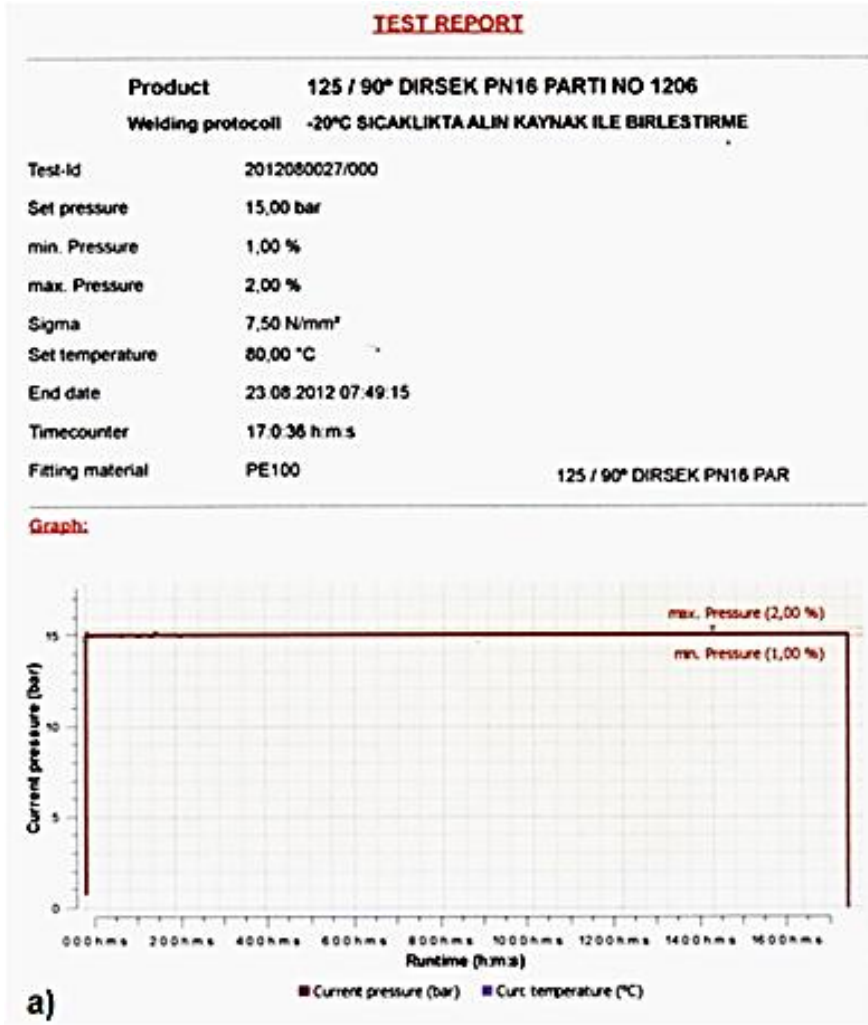

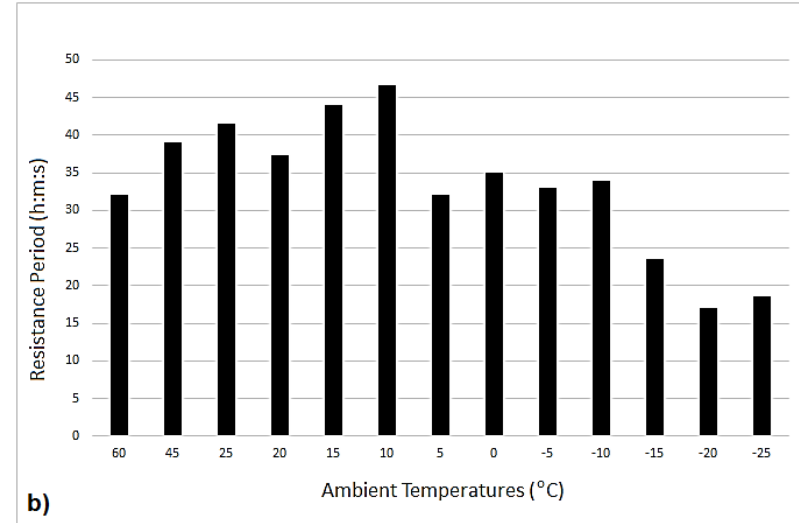

Figure 9: Hydrostatic internal pressure test rapport and Blow-up periods of samples welded at different ambient temperatures and applied 7.5 MPa circular tension.

\section{Conclusion}

When the results achieved from this experimental study are evaluated;

- The most disadvantageous side of the butt fusion welding is its low bending resistance that is the resistance against the tensions at axial direction.

- There is no permanent damage (cracking, distortion, denting, bulging, etc.) found on the bead and its surroundings when the sample surfaces achieved from the joining processes made at temperatures between $-25^{\circ} \mathrm{C}$ and $60^{\circ} \mathrm{C}$ are analyzed.

- The ambient temperature has a major effect on welding quality. However, excellent results are achieved by the changes in recommended standard parameters even at non-recommended ambient temperatures. We can attribute it to the talents of recently produced welding machines.

- When the results achieved in the tests are evaluated, their tensile strength show variation between $21 \mathrm{MPa}$ to $27 \mathrm{MPa}$.

- During the tests depending on EN 1167-1 standards, there is no permanent deformation on any samples at any ambient (welding) temperatures.

- During the tests carried out by increasing the circular tension, while blow-ups (detachments) occurs on the welding area in the welding processes at the ambient temperatures of $-15^{\circ} \mathrm{C}$ or lower, at all other ambient temperatures, the detachments occur except the welding area (on the pipe).

\section{Acknowledgment}

This study is supported by NTG Plastic Industry and Trade Corporation.

\section{References}

[1] Anık S, Dikicioğlu A, Vural M. Termoplastik Malzemelerin Kaynağı. Kaynak Tekniği Derneği. İkinci Baskı. İstanbul, Türkiye, Birsen Yayınevi, 1994.

[2] Akkurt A, Ertürk İ. "Sıcak Elaman Alın Kaynak Yöntemi ile Birleştirilen PE Doğalgaz Borularının Güvenirliklerinin Araştırılması". Pamukkale Üniversitesi Mühendislik Bilimleri Dergisi, 16(2), 221-233, 2010.

[3] Akkurt A, Sarac E. "Sıcak Alın Kaynak Yöntemi ile Farklı Sıcaklıklarda Birleştirilen PE Doğalgaz Transfer Hatlarının Güvenirliklerinin Araștırılması". $2^{\text {nd }}$ International Conference on Welding Technologies and Exhibition. Ankara, Türkiye, 23-24-25 May 2012.

[4] Electrofusion fittings: http://www.agru.at/fileadmin/ user_upload/download_pdf/3. Industrierohrsysteme_D_E high.pdf, (12.03.2014).

[5] Welding Methods of HDPE Pipe and Fittings: http://www.sangir.in/pdf/HDPE-Pipes-Fittings.pdf (11.03.2014)

[6] Benkreira H, Day AJ, Shillitoe S. "Butt Fusion Joining of Polyethylene Pipes: A Theoretical Approach. Advances in Joining Plastics and Composites". International Conference, Bradford, Yorkshire, UK, 10-12 June 1991.

[7] Benkreira H, Shillitoe S, Day AJ. "Modelling of the Butt Fusion Welding Process". Chemical Engineering Science, 46(1), 135-142, 1991. 
[8] Mohammad R, Khalil K, Mohammad FG. "Analysis of Effect of Pressure and Heat on Mechanical Characteristics of Butt Fusion Welding of Polyethylene Pipes". Polymer-Plastics Technology and Engineering, 50(9), 907-915 2011.

[9] Micheal J. Troughton. Handbook of Plastics Joining, Editors: Troughton, MJ. Polyethylene Joining Procedures, 353-370, Plastics Pipe Institute, USA, Washington DC, Press, 2006.

[10] Lear JJ. Slow Crack Growth and Associated Plastic Deformation in Linear Medium-Density Polyethylene, Ph.D Dissertation. University of Illinois at Urbana-Champaign, Champain, USA, 1990.

[11] Lu XC, Zhou ZQ, Brown N. "A Sensitive Mechanical Test for Slow Crack Growth in Polyethylene". Polymer Engineering and Science. 37(11), 1896-1900, 1997.

[12] NTG Plastik San. ve Tic. AȘ. http://www.ntgplastik.com/ pdf/teknico english.pdf (27.02.2014).

[13] Egen U. "Structure in Heating Element Welding Seams at Polypropylene Pipes, Welding Research Reports". Welding Research Reports Volume 4, DVS GmbH, Düsseldorf, Germany, 1985.

[14] DesLauriers PJ, McDaniel MP, Rohlfing DC, Krishnaswamy RK, Secora SJ, Benham EA, Maeger PL, Wolfe AR, Sukhadia AM, Beaulieu BB. "A Comparative Study of Multimodal vs. Bimodal Polyethylene Pipe Resins for PE-100 Applications". Polymer Engineering and Sciene. 45(16), 1203-1213, 2005.
[15] Marley New Zealand Limited. http://www.marley.co.nz /afawcs0119272/CATID=4/SUBID=74/ID =148/SID =877 417560/PE-Systems.html (23.12.2010).

[16] International Standard Organization. "ISO 13953 : 2001Polyethylene (PE) Pipes and Fittings-Determination of The Tensile Strength and Failure Mode of Test Pieces From A Butt Fused Joint". http://www.iso.org/iso/catalogue_detail.htm?csnumber= 23417 (15.05.2014).

[17] Beech SH, Griese J, Lowe D, Vanspeybroeck P. "Harmonization of Polyethylene Pipe Butt Fusion Procedures and Test Methods". 2nd WJS/DVS Conference on Joining Plastics Handwerkskammer, Düsseldorf, Germany, 2 November 2010.

[18] International Standart Organization. "ISO 11414: 2009-Plastics Pipes and Fittings-Preparation of Polyethylene (PE) Pipe/Pipe or Pipe/Fitting Test Piece Assemblies by Butt Fusion". http://www.iso.org/iso/catalogue_detail.htm?csnumber= 43864 (21.05.2014).

[19] Barber P, Atkinson JR. "The Use of Tensile Tests to Determine the Optimum Conditions for Butt Fusion Welding Certain Grades of Polyethylene". Polybutene-1 and Polypropylene Pipes. Journal of Materials Science, 9(9), 1456-1466, 1974.

[20] Polysmart/Pmbweld301b/Butt Weld/PE Pipelines Resource

Manual:http://training.polysmart.com.au/ docs/BW Res ource_Manual.pdf (17.12.2013). 